\title{
FACTORS WHICH GOVERN THE SELECTION OF PRACTICAL SUSTAINED YIELD WORKING CIRCLES IN SASKATCHEWAN.
}

\author{
By E. H. RoBerts, \\ Director of Forests, Saskatchewan
}

\begin{abstract}
$\mathrm{T}$ HIS paper will confine itself chiefly to a description of an attempt to determine if a working plan and budget could be put into effect in a large operation in Saskatchewan. In this attempt it was necessary to study and evaluate the factors involved. A large sawmill had been in operation for years. The location and general topography are such that this mill is the only practical outlet for saw-timber from a very large district lying up-river and to the west of it. The market, or at least the place of manufacture into lumber is, therefore, fixed. As the establishment is large, there would be difficulty in moving the mill farther to the west so as to be nearer to the timber in the western district when this is being cut. As the mill is situated now, it is at the focal point of a very large territory, and since all of the timber is driven by river for at least part of the distance, it would appear the most natural location for it.
\end{abstract}

\section{Mill Size}

The mill has a capacity of $175 \mathrm{M}$. in ten hours. While the annual production of the plant has been as high as 50 million board feet, it has been operated during times of poor markets as low as $2 \frac{1}{2}$ million. It is claimed by company officials that the mill cannot be run economically on less than an annual cut of 20 million board feet.

We submit at the outset that this is the wrong method of determining the size of the operation and the area which should be made tributary to the mill. But it is the old story that the larger and more efficient the equipment and the greater the output of the mill, the greater will be the returns per unit of investment and labour. These are the factors which have governed the size of the sawmills cutting virgin stands of mature timber, and as they are well known, they are used almost as sole guides in determining mill set-up. These mills are admittedly built and run on the principle of destruction of a large forest capital, made available by nature, and there is no thought of making the operation continuous.

It is only when the end of supply of old growth timber is in sight that the owners begin to look around for ways and means to keep the operation going. Often the "Goose that laid the golden egg is given a shot in the arm" by buying timber from adjacent sources or cutting in stands not considered merchantable at one time. But it is a losing game and the evil day when the mill must close for the last time is merely postponed.

Of course at the time this mill was established the factors of available supply and rate of growth were not known. Even the territory tributary to the mill was largely unexplored. All that was done was to obtain cutting rights on timber berths, which included the easily accessible timber adjacent to the main watercourses. Thus a supply for 25 to 30 years was assured. Always there was in the background that imponderable and intriguing factor, the annual growth which might turn the young and undersized stands into 
merchantable timber during the time the old growth was being harvested.

Although definite statistics are lacking, it is probable that, at the time this investigation was made, not less than 600 million board feet had already been cut. The available supplies left have been estimated at 400 million.

\section{Area Distribution}

In this investigation a tentative area of about 3,000 square miles was laid out as economically tributary to the mill. This seems a very large area, but much of it is sparsely timbered. It has been roughly subdivided as follows:

Forest Cover

Merchantable timber

Small growth

Cut-over timber berths

Productive Forest Land Muskeg and untyped

Total area of Working Circle
Area

Square Miles

430.06

485.47

290.63

1206.16

1751.64

2957.80

Much of this subdivision was made from aerial photographs, but as indicated, large areas have not been so examined.

\section{Forest Conditions}

This region has a continental climate modifed by its northern position and the forest reflects the climate associated with such a location. It is a very different forest from that in other regions, such as in eastern Canada or British Columbia. The timber is scattered in blocks over a big area, and much of it is in the mixedwood cover-type. The species upon which the sawmill industry is based is white spruce, which on favourable sites grow to a very large size. Jack pine and black spruce, however, also occur in merchantable quantities but take a subsidiary place in the output of the sawmill to that of white spruce.

The main drainage is from west to east and all the wood is driven to the mill during the spring floods. This does not mean, however, that water is the only means of transportation. Large areas must be served by long-haul roads on which tractor trains are used. But all these major main hauls end at the main river or the larger tributaries.

Much of the area is either flat or of little elevation, with the exception of a highland to the south, which is part of the Manitoba escarpment. During and since the glacial age much surface geological action has taken place. The clear expression of this geological history in terms of surface deposits and topography, makes it possible to subdivide the area into site-groups which are known to differ in quality and growth potentialities. These site-groups have been designated as, Plateau, Transition, Glacial Slope, Lacustrine, Delta and Alluvial. These various site groups can be distinguished in air photographs. In combination with the ordinarily recognized cover types of softwood, mixedwood and hardwood, these site-groups make possible the recognition of eighteen subdivisions.

\section{Stand Tables and Growth}

Several surveys and growth studies on cut-over lands have made available 
fairly representative data from which stand tables and growth curves for three of the site-groups which occupy most of the area have been completed. By means of graphical analysis, the average annual increment, interval between possible equal annual cuts and the equivalent diameter limit, were calculated. Then also an estimate of the total saw-timber available had been made by means of the air survey and general ground-survey data. As noted above this amounts to approximately 400 million board feet.

\section{Budget and Rotation}

It was found that a cutting cycle averaging 20 years in length and diameter limits of 12 inches D.B.H. on the uplands and 16 inches D.B.H. on the lowlands, equivalent to a rotation of 125 years, would provide an annual cut of over 15 million feet board measure of white spruce. This is the estimated production from lands yet uncut and which would be cut under these diameter limits, or only about 430 of the 1200 square miles of productive forest lands. Of the remainder, 485 square miles is in small growth and would undoubtedly supply a very large quantity in the future and 290 square miles is in cut-over timber berths. Unfortunately, on account of the destructive method by which these lands have been cut, it will be a very long time before these cut-over lands will again yield white spruce of sawlog size. Then too, the 1751 square miles of muskeg and untyped stands, on the latter of which little is known in regard to growth, are possible sources of large amounts of saw timber. It is hardly safe, however, to place the annual productive capacity beyond 20 million feet board measure.

\section{Practical Application}

As would be expected, the company concerned did not think that their operations at this late date could be converted to operate on the basis outlined. Admittedly the growth data, on which this investigation was based, were meagre when the size of the working circle is considered, and there is a great chance for error. Then also it was tacitly assumed that regeneration of white spruce would be much better under the selection method of operation, which is what such high diameter limits amounts to. Such has not been proven for these northwestern forests and the regeneration of this species under this method of operation may not be enough to stock the stands even at their present capacities, let alone improving the stocking. This, by the way, is generally sparse and the means to improve it by an economic cutting method has not been determined.

While we were unsuccessful in the attempts to place this very large operation on a sustained yield basis, the attempt has shown us some of the factors and their evaluation which must be considered if it is tried elsewhere in our province. Our chief hopes for sustained yield operation are from the operation of smaller-sized manufacturing units. The large mills will be supplanted eventually by many of these smaller units which have so many advantages, chief of which are the small charge for depreciation and obsolescence and local markets for small dimension and low grade lumber. The small annual cut which may be made economically with such units, will allow smaller working circles to be set up. The size of these, while primarily determined by topography, cannot be decided until, by investigation and experimentation, we are able to determine more accurately for each district the factors of annual growth and methods of regeneration. 


\section{Other Considerations}

Fire occurrence in the tentative working circle area investigated had been low prior to the survey as compared to other parts of the province. Seasonal precipitation has decreased and water levels have receded very greatly during the past decade, which factors, coupled with more traffic and activity throughout the area, have tended to very materially increase the fire risk. In forecasting an annual cut on a sustained yield basis in such an area, damage and loss by fire, wind, insects and disease should not be overlooked. Where diameter limits are increased, as proposed in this case to insure future operations, the matter of additional logging costs have to be considered to determine whether a profitable operation will result. More efficient extraction methods, the possibility of year round logging and adjustment of plant facilities to the utilization of other forest products from the area are additional factors that may greatly affect the economic feasibility of placing the operations on a sustained yield basis. This investigation has shown that, had sustained yield for this area been recognized some years ago, before the greater part of the area had been cut over, the timber supplies then available would have been sufficient and the proposal possible. The facts brought out by the study provide adequate data on which to base more conservative cutting in future sales of provincial timber by less severe marking or increased diameter limits, so as to leave a larger residual stand and the probability of obtaining more adequate regeneration on the cut-over areas.

A commendable feature of this investigation was the co-operative spirit and effort demonstrated throughout by the lumber company concerned and the federal and provincial government forest services. Much valuable private information was supplied by the lumber company.

It is desired here to give due credit to the Dominion Forester and Messrs. G. A. Mulloy and V. H. Phelps for their assistance in assembling the main facts and determining the proposed budget and rotation set out in this paper.

\section{CONDENSEd Summary OF Report on Fire OCCURRENCE IN The Pas Working Circle}

A total of 126 fires reported during the past 25 year period (1916-40) within the proposed working circle area shows a net area of 403 square miles as having been burned over, or 14 per cent of the total. This represents an average yearly burn of 16.1 square miles or .54 per cent for the 25 year period. For the 15 year period prior to 1931 some 26 fires as reported burned over 10 per cent of the working circle. During the past 10 years 100 fires reported indicate a total burn of 4.24 per cent of the working circle area.

Although the past decade has been one of excessive drought conditions and increased activity in the area, it is significant that with four times as many fires, the area burned was only one quarter that during the previous 15 year period.

In considering the productive forest land only, it appears that $181 / 2$ per cent of this area has been damaged by fire during the past 25 year period. In considering this history of fire occurrence, it may be assumed that the future fire risk within the working circle will be within the limits of the past provided weather conditions return to normal and economic pressure does not force attempts at further settlement inside the circle. 